\title{
Population characteristics of cephalolichen Lobaria pulmonaria (L.) Hoffm. at the northern limit of its range (Northwest Russia, Republic of Karelia)
}

\author{
Roman Viktorovich Ignatenko ${ }^{1,2^{*}}$, Victoria Nikolaevna Tarasova ${ }^{3}$ \\ ${ }^{1}$ Karelian Research Centre of the Russian Academy of Sciences, Pushkinskaya St. 11, \\ Petrozavodsk 185910, Russia \\ ${ }^{2}$ Petrozavodsk State University, Department of General Chemistry, Lenin Av. 33, \\ Petrozavodsk 185910, Russia \\ ${ }^{3}$ Petrozavodsk State University, Department of Botany and Plant Physiology, Lenin Av. \\ 33, Petrozavodsk 185910, Russia
}

\begin{abstract}
The populations of Lobaria pulmonaria and their characteristics were studied at the northern limit of its range in the Republic of Karelia (Northwest Russia). The study was carried out in northernmost boreal zone on 8 permanent $100 \times 100 \mathrm{~m}$ sample plots with last disturbance 180-270 years ago. It was found that in the north of the region, the number of substrate units on which lichen grows decreases with an increase of the time since last disturbance from 25 to 11 per ha. In the ontogenetic spectrum (excluding juvenile and immature thalli), virginal thalli prevailed. The proportion of generative thalli in forests in the mid-succession stages (mixed spruce-birch forests) was $2 \%$, and they were absent at later stages (in preclimax spruce forests). In the studied forests, the main substrate of Lobaria pulmonaria was the trunks of living Populus tremula and Salix caprea. With an increase in the diameter and area of the trunk of Populus tremula, the number of thalli increased, and their average area decreased. An important role for Lobaria pulmonaria was played by the individual characteristics of the tree trunk, such as the height above ground, exposure, angle of inclination. The optimal conditions for the growth and development of this species were formed on the aspen trunks. Due to the collecting shape of crown and its wide radius, a large amount of precipitation flowed down the trunk during rain. Moreover, due to the wide and dense crown, the trunks were wet longer than other tree species. Comparison of the obtained data with similar studies done in the subzone of the middle taiga showed that at the limit of the range, the number of substrate units colonized by Lobaria pulmonaria and the number of thalli was smaller than in the south of Karelia. The share of generative thalli in the ontogenetic spectrum of species populations in forest communities of the north taiga subzone was 3 times smaller than in the middle taiga forests.
\end{abstract}

Key words: northern taiga ecosystems, time from last disturbance, population ecology, populations, populations at range limits

DOI: $10.5817 / \mathrm{CPR} 2020-2-18$

Received August 3, 2020, accepted December 23, 2020.

*Corresponding author: R. Ignatenko <ocean-9@mail.ru>

Acknowledgements: The study was carried out according to the state order in the Karelian Research

Centre of the Russian Academy of Sciences. 


\section{Introduction}

Epiphytic cephalolichen Lobaria pulmonaria (L.) Hoffm. is widespread in the boreal, temperate, montane and oceanic areas in the Northern Hemisphere and in cool tropical areas (Yoshimura 1998). It is believed that the species has a continuous range, however, at present, L. pulmonaria is found at different spots with different frequency. Over the past 60 years, the world population of $L$. pulmonaria has declined significantly, and the species is currently threatened with extinction in many countries of Western Europe due to the destruction of its habitat and atmospheric pollution (Clerc et al. 1992, Gauslaa 1995, Scheidegger et al. 1998, Zoller et al. 1999, Goward and Arsenault 2000, Gu et al. 2001, Richardson and Cameron 2004, Jüriado and Liira 2009, Scheidegger et al. 2012).

In the European part of Russia, L. pulmonaria is widely represented in the south of the Republic of Karelia (Kravchenko and Fadeeva 2008), in the north of Arkhangelsk region (Batalov et al. 2005) and in the Komi Republic (Pystina and Semenova 2009). In forest phytocoenoses in northern Russia (Murmansk Region, Nenets Autonomous Okrug) L. pulmonaria is rare $[1,2]$.

It is known that species populations at range limits are more vulnerable to adverse environmental factors (Sidorova and Churakova 2010, Markovskaya et al. 2018, Kadetov and Suslova 2019). According to the data of Kravchenko and Fadeeva (2008), at L. pulmonaria range limits in northwestern Russia there is no real threat to its existence. However, when conducting this study, only L. pulmonaria presence-absence data were taken into account.

At the same time, studies of the antioxi-

\section{Materials and Methods}

The studies were carried out in 20142016 in Northwest Russia, in the northern taiga forest communities of the Republic dant enzyme activities (superoxide dismutase and catalase) in the L. pulmonaria thalli at different ontogenetic stages revealed significant differences between coenopopulations in forests in subzones of middle and northern taiga in northwestern Russia (Chirva et al. 2019). For example, a decrease in catalase activity in young thalli in the forest in the north taiga subzone may indicate their stress response to environmental conditions.

A study carried out in the forests in the middle taiga subzone showed that with an increase in the time since last disturbance from 80 to 450 years, the total number of L. pulmonaria thalli and the number of colonized substrate units increase as well, with no stabilization of these indices being observed in the series of communities studied (Ignatenko and Tarasova 2017, 2018). The restoration of the total area of thalli in phytocoenoses occurs after 200 years since severe disturbance. In old-growth forests (> 400 years old), L. pulmonaria colonize a broad spectrum of tree species in different life states, including lower branches of young spruce trees. At that, the share of regressive subpopulations decreases, while the share of colonizing subpopulations increases, which indicates successful reproduction of the species.

For a complex assessment of L. pulmonaria status at its range limits, it was necessary to study the size and ontogenetic structure of lichen populations in the communities, substrate preference, and the influence of habitat conditions (at the community, tree, and microenvironment level) on the qualitative and quantitative characteristics of the species.

of Karelia. The relief of the territory is a hillyplain with prevailing heights from 5 to $250 \mathrm{~m}$ above sea level (Biske 1959). The 
climate is temperate, transitional from maritime to continental. The average annual air temperature varies from $+3^{\circ} \mathrm{C}$ (in the south) to $0^{\circ} \mathrm{C}$ (in the north). The territory belongs to a zone with a high humidity with an average annual rainfall of $550-750 \mathrm{~mm}$, which decreases from south to north (Romanov 1961). Most of the territory (54\%) of the Republic of Karelia is covered by forests. Pine (Pinus sylvestris L.) phytocoenoses predominate, they account for $64 \%$ of the forested area, spruce (Picea abies (L.) H. Karst, Picea obovata Ledeb., Picea $\times$ fennica (Regel) Kom.) forests occupy $24 \%$, birch (Betula pendula Roth, Betula pubescens Ehrh.) forests - 11\%, aspen (Populus tremula L.) forests $\sim 1 \%$. Pine forests prevail in the north, while spruce and deciduous forests dominate in the south of the region (Volkov 2008). Major forest disturbance factors in Karelia are felling, fire and windfall (Gromtsev 2008). Over the past 100 years, most of Karelian forests were clear-cut. The current frequency of forest fires in Northwest Russia is $1-2$ times a century ( $\sim 60$ years) for drained habitats and 1-2 times a millennium for waterlogged ones (Gorshkov 1998, 2001; Gromtsev 2007). However, in Karelia (the westernmost in the Eurasian taiga zone and the last in Fennoscandia), relatively large fragments of native forests are preserved. They account for $\sim 9 \%$ of the region total area (Gromtsev 2003).

The work was carried out in two strictly protected areas - in Kostomuksha Nature Reserve and Paanajarvi National Park in two types of forest phytocoenoses: (1) grass-bilberry mixed spruce-birch communities (180-200 years since last disturbance) and (2) sub-climax bilberry feathermoss spruce forest (210-270 years since last disturbance).

Data collection was carried out on 8 permanent $100 \times 100 \mathrm{~m}(1 \mathrm{ha})$ sample plots (SP) arranged according to the requirements adopted in geobotany. On each SP, geobotanical descriptions were performed, including the characteristics of forest communities (time since last disturbance, the share of particular tree species in the forest stand, the sum of cross-section areas of the trees, the crown density, soil cover characteristics) and individual trees (age, height, trunk diameter, substrate area from 0 to $2 \mathrm{~m}$ above ground, crown parameters) (Andreeva et al. 2002). To assess the time since last disturbance the method of studying tree (first of all, Picea spp.) population structure was used (Stavrova et al. 2016).

The thallus indices of L. pulmonaria were recorded by total counting on all substrates at a height of 0-2 $\mathrm{m}$ above ground. At the places of species growth, the characteristics of microconditions were recorded: trunk exposure, the height above ground, the angle of inclination of the trunk surface. For each thallus of L. pulmonaria, the total area and necrotic area $\left(\mathrm{cm}^{2}\right)$ were measured using the $25 \times 25 \mathrm{~cm}$ frame. Also ontogenetic state was determined: virgin $1(\mathrm{v} 1)$, virgin $2 \mathrm{a}(\mathrm{v} 2 \mathrm{a})$, virgin $2 \mathrm{~b}(\mathrm{v} 2 \mathrm{~b})$, virgin $2 \mathrm{c}(\mathrm{v} 2 \mathrm{c})$, generative (g), sub-senile (ss), senile (s) (Mikhailova 2005, Ignatenko et al. 2020). Based on the spectrum of thalli of different ontogenetic states, the following types of subpopulations were distinguished: colonizing ( $\mathrm{col}$ ), extending (ext), stable (st), pseudo-extending (ps-ext), retrogressive (retr). All talli growing on the same tree were attributed to onesubpopulation.

Statistical data processing was based on regression analysis using the linear model: $y=a X+b$ (Andreeva et al. 2002, Ivanter and Korosov 2011). If there were relationships, the lines on the graphs were drawn in accordance with the regression model. In the absence of significant changes, a horizontal line at the average value was drown on the graph.

A total of 898 thalli of L. pulmonaria growing on 120 substrate units (standing or fallen living or dead trees and shrubs) were recorded. 
R. V. IGNATENKO and V. N. TARASOVA

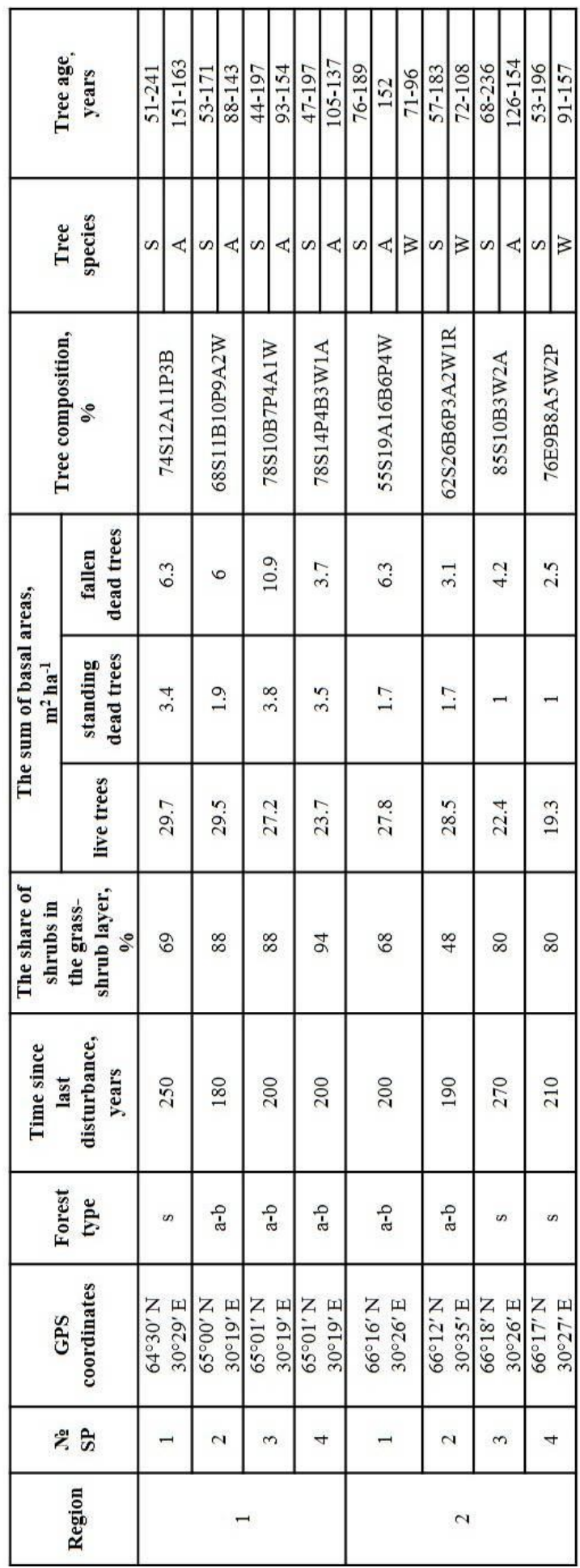

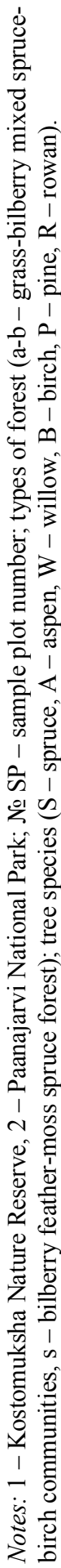




\section{Results}

It was found that in northern taiga mixed spruce-birch communities, the number of thalli varies from 63 to 232 pcs per ha, averaging at 125 pcs per ha, while in spruce forests the number of thalli varies from 73 to 123 pcs per ha and averages at 91 pes per ha. Probably, a smaller number of thalli in spruce forests is related to a decreased ability of potential substrate for L. pulmonaria. Thus, the share of deciduous tree species (the main forophytes for L. pulmonaria) in the stand is higher in spruce-birch phytocoenoses than in subclimax spruce forests, and averages 23 and $18 \%$, respectively. At the same time, an in-

(A)

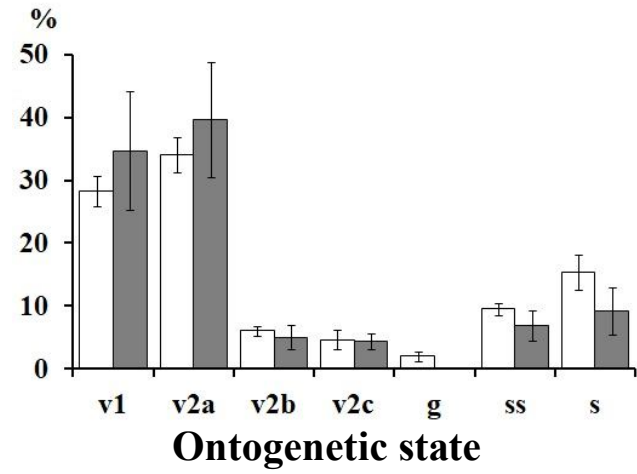

crease in the time since last disturbance from 180 to 270 years decreases by half the number of substrate units on which the lichen grows (from 25 to 11 pcs per ha $\left.\left(R^{2}=0.62 ; p=0.05\right)\right)$.

In the ontogenetic spectrum of populations of L. pulmonaria (excluding juvenile and immature thalli), in most cases $(70 \%)$ virginal thalli dominate (Fig. 1.A), and the share of sub-senile and senile thalli is on average 9 and $13 \%$, respectively. It is to be noted that in spruce forests there are no thalli with apothecia, and in mixed sprucebirch forests they account for only $2 \%$.

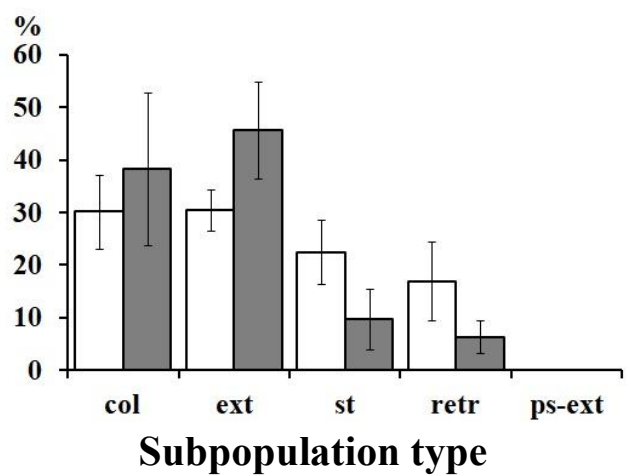

Fig. 1. (A) Age-related spectra of populations and (B) the share of various types of subpopulations of Lobaria pulmonaria in the phytocoenoses in the subzone of the northern taiga of Karelia. Notes: white - grass-bilberry mixed spruce-birch forests, gray - bilberry feather-moss spruce forests.

In the subpopulation spectrum(Fig. 1.B), in communities with the time since last disturbance of 180-200 years, colonizing and retrogressive subpopulations account for $30 \%$ each, and in phytocoenoses with the time since last disturbance of 210-270 years, 38 and $46 \%$, respectively. It was found that in mixed spruce-birch communities, the share of stable and regressive subpopulations in the total spectrum is 2 times higher than in bilberry feather-moss spruce forest.
In the studied phytocoenoses, L. pulmonaria colonizes mainly deciduous trees - Populus tremula (45\%), Salix caprea (43\%), Sorbus aucuparia (5\%), Betula spp. (4\%) (Table 2, 3). Single thalli were found on the branches of Picea spp. (3\%). At the same time, $74 \%$ of the substrate units of L. pulmonaria are represented by living trees, $18 \%$ are standing dead trees, and $8 \%$ are fallen dead trees. On the fallen dead trees, L. pulmonaria was most often found on $S$. caprea trunks $(75 \%)$. It is important 
to note that in the bilberry feather-moss spruce forest, thalli of L. pulmonaria colonize a smaller variety of substrates (Table 3). Thus, in mixed spruce-birch communities, the species was recorded on fallen dead mountain ash and aspen, while it did not grow on these types of substrate in sub-climax spruce communities.

Interestingly, in the north-taiga communities, the average thallus area on the trunks of two main phorophytes (P. tremula and $S$. caprea) differs significantly (Table 3 ). Thus, in mixed spruce-birch communities, the average thallus area of $L$. pulmonaria on $S$. caprea is $507.7 \pm 120.2 \mathrm{~cm}^{2}$, and on $P$. tremula is $51.2 \pm 14.1 \mathrm{~cm}^{2}$ (U-test, $\mathrm{p}=0.001)$. In bilberry feather-moss spruce forest, a similar trend is observed that on $S$. caprea the average area of thalli is $210.8 \pm 98.4 \mathrm{~cm}^{2}$, and on P. tremula -35.7 $\pm 8.4 \mathrm{~cm}^{2}$ (U-test, $\mathrm{p}=0.05$ ). Such differences are due to the fact that on the willow trunks in the subpopulation spectrum there are $\sim 1.5$ times fewer thalli with a small area of virginal $1,2 \mathrm{a}, 2 \mathrm{~b}$ states than on aspen trees. Also, on the trunks of $S$. caprea, the proportion of regressive subpopulations is 12 times higher than on the trunks of $P$. tremula.

\begin{tabular}{|c|c|c|c|c|c|c|c|c|c|c|}
\hline $\begin{array}{c}\text { Forest } \\
\text { type }\end{array}$ & Substrate & $\mathbf{N}$ & Age & $\boldsymbol{H}$ & $\boldsymbol{H}_{c r}$ & $\boldsymbol{L}_{c r}$ & $D_{0}$ & $D_{130}$ & $\boldsymbol{R}_{c r}$ & $S$ \\
\hline \multirow{4}{*}{$\mathrm{a}$} & Picea spp. & 2 & $\begin{array}{l}\mathbf{9 2 . 5} \\
\pm 0.5 \\
\end{array}$ & $\begin{array}{r}11.5 \\
\pm 4.5 \\
\end{array}$ & $\begin{array}{c}\mathbf{6 . 3} \\
\pm 3.8 \\
\end{array}$ & $\begin{array}{c}\mathbf{5 . 3} \\
\pm 0.8 \\
\end{array}$ & $\begin{array}{l}\mathbf{1 5 . 1} \\
\pm 6.5 \\
\end{array}$ & $\begin{array}{l}\mathbf{1 3 . 5} \\
\pm 5.9 \\
\end{array}$ & $\begin{array}{c}\mathbf{1 . 0} \\
\pm 0.2 \\
\end{array}$ & $\begin{array}{c}\mathbf{0 . 9} \\
\pm 0.4 \\
\end{array}$ \\
\hline & Populus tremula & 34 & $\begin{array}{c}\mathbf{1 1 7 . 1} \\
\pm 3.9 \\
\end{array}$ & $\begin{array}{l}\mathbf{2 1 . 0} \\
\pm 0.6 \\
\end{array}$ & $\begin{array}{l}\mathbf{1 3 . 2} \\
\pm 0.7\end{array}$ & $\begin{array}{c}\mathbf{7 . 8} \\
\pm 0.6 \\
\end{array}$ & $\begin{array}{l}\mathbf{3 6 . 4} \\
\pm 1.9 \\
\end{array}$ & $\begin{array}{l}\mathbf{3 1 . 7} \\
\pm 1.5 \\
\end{array}$ & $\begin{array}{c}\mathbf{2 . 5} \\
\pm 0.1 \\
\end{array}$ & $\begin{array}{c}\mathbf{2 . 1} \\
\pm 0.1\end{array}$ \\
\hline & Salix caprea & 27 & $\begin{array}{l}\mathbf{8 7 . 6} \\
\pm 4.5 \\
\end{array}$ & $\begin{array}{l}\mathbf{1 2 . 6} \\
\pm 0.6\end{array}$ & $\begin{array}{c}\mathbf{6 . 3} \\
\pm 0.5\end{array}$ & $\begin{array}{c}\mathbf{6 . 3} \\
\pm 0.5\end{array}$ & $\begin{array}{l}\mathbf{3 1 . 1} \\
\pm 2.3\end{array}$ & $\begin{array}{l}\mathbf{2 3 . 2} \\
\pm 1.3\end{array}$ & $\begin{array}{c}\mathbf{1 . 6} \\
\pm 0.1\end{array}$ & $\begin{array}{c}\mathbf{1 . 6} \\
\pm 0.1\end{array}$ \\
\hline & Sorbus auc & 3 & $\begin{array}{l}\mathbf{7 8 . 5} \\
\pm 5.5 \\
\end{array}$ & $\begin{array}{l}\mathbf{1 0 . 7} \\
\pm 1.8 \\
\end{array}$ & $\begin{array}{c}\mathbf{6 . 3} \\
\pm 1.2 \\
\end{array}$ & $\begin{array}{c}\mathbf{4 . 3} \\
\pm 0.9 \\
\end{array}$ & $\begin{array}{l}\mathbf{1 3 . 5} \\
\pm 0.4\end{array}$ & $\begin{array}{l}\mathbf{1 2 . 2} \\
\pm 1.0 \\
\end{array}$ & $\begin{array}{c}\mathbf{1 . 3} \\
\pm 0.1\end{array}$ & $\begin{array}{c}\mathbf{0 . 8} \\
\pm 0.1\end{array}$ \\
\hline \multirow{3}{*}{$\mathrm{b}$} & Picea spp. & 2 & $\begin{array}{l}\mathbf{6 4 . 0} \\
\pm 0.0 \\
\end{array}$ & $\begin{array}{c}\mathbf{2 . 5} \\
\pm 4.8\end{array}$ & $\begin{array}{c}\mathbf{1 . 0} \\
\pm 2.4\end{array}$ & $\begin{array}{c}\mathbf{1 . 6} \\
\pm 4.1\end{array}$ & $\begin{array}{c}\mathbf{5 . 3} \\
\pm 8.6\end{array}$ & $\begin{array}{c}\mathbf{4 . 1} \\
\pm 8.1\end{array}$ & $\begin{array}{c}\mathbf{0 . 8} \\
\pm 0.7\end{array}$ & $\begin{array}{c}\mathbf{0 . 3} \\
\pm 0.02 \\
\end{array}$ \\
\hline & Populus tremula & 13 & $\begin{array}{c}\mathbf{1 4 3 . 6} \\
\pm 6.5\end{array}$ & $\begin{array}{l}\mathbf{2 5 . 5} \\
\pm 1.9\end{array}$ & $\begin{array}{l}\mathbf{1 7 . 5} \\
\pm 0.9\end{array}$ & $\begin{array}{c}\mathbf{8 . 0} \\
\pm 1.6\end{array}$ & $\begin{array}{l}\mathbf{5 2 . 3} \\
\pm 3.4\end{array}$ & $\begin{array}{l}\mathbf{4 3 . 2} \\
\pm 3.2\end{array}$ & $\begin{array}{c}\mathbf{2 . 4} \\
\pm 0.3\end{array}$ & $\begin{array}{c}\mathbf{3 . 0} \\
\pm 0.2\end{array}$ \\
\hline & Salix caprea & 6 & $\begin{array}{l}\mathbf{1 2 4 . 0} \\
\pm 33.0\end{array}$ & $\begin{array}{l}\mathbf{1 3 . 2} \\
\pm 0.9\end{array}$ & $\begin{array}{c}7.2 \\
\pm 1.1\end{array}$ & $\begin{array}{c}\mathbf{6 . 0} \\
\pm 1.1\end{array}$ & $\begin{array}{l}\mathbf{3 5 . 9} \\
\pm 7.6\end{array}$ & $\begin{array}{l}\mathbf{2 8 . 6} \\
\pm 6.4\end{array}$ & $\begin{array}{c}\mathbf{1 . 5} \\
\pm 0.2\end{array}$ & $\begin{array}{c}\mathbf{2 . 0} \\
\pm 0.4\end{array}$ \\
\hline
\end{tabular}

Table 2. Taxation parameters of the main substrates of Lobaria pulmonaria in forest communities of Karelia in the north taiga subzone. Notes: Forest type: a - grass-bilberry mixed spruce-birch communities, $\mathrm{b}$ - sub-climax bilberry feather-moss spruce forest. $\mathrm{N}-$ The number of substrate units. Taxation parameters of trees are indicated as: Age - tree age, years; $\mathrm{H}$ - tree height, $\mathrm{m}$; $\mathrm{D}_{0}$ - trunk diameter at the base of the tree, $\mathrm{cm} ; \mathrm{D}_{130}$ - trunk diameter at a height of $1.3 \mathrm{~m}$; $\mathrm{H}_{\mathrm{cr}}$ - height of the lower boundary of the crown, $\mathrm{m} ; \mathrm{L}_{\mathrm{cr}}-$ the length of the crown, $\mathrm{m} ; \mathrm{R}_{\mathrm{cr}}-$ the radius of the crown, $\mathrm{m} ; \mathrm{S}-$ substrate area, $\mathrm{m}^{2} . \mathrm{M} \pm \mathrm{m}$ : $\mathrm{M}$ - average value, $\mathrm{m}$ - standard error.

It was found that with increasing age of the main substrate of $L$. pulmonaria living $P$. tremula trees from 90 to 160 years, the following taxation parameters of the tree increase: trunk diameter (at a height of $1.3 \mathrm{~m})$ - from 30 to $48 \mathrm{~cm}\left(\mathrm{R}^{2}=0.74\right.$; $\mathrm{p}=0.001)$, the crown radius - from 2.3 to $3.2 \mathrm{~m}\left(\mathrm{R}^{2}=0.65 ; \mathrm{p}=0.05\right)$, the height - from 20 to $27 \mathrm{~m}\left(\mathrm{R}^{2}=0.60 ; \mathrm{p}=0.05\right)$, the substrate area - from 1.9 to $3.2 \mathrm{~m}^{2}$ $\left(R^{2}=0.75 ; p=0.05\right)$. With the tree growth, the physical and chemical properties of the substrate, the moisture and light conditions change, and the time required for the colonization, growth and development of lichens increases. 


\begin{tabular}{|c|c|c|c|c|c|}
\hline Forest type & Substrate & $\begin{array}{c}\text { The } \\
\text { number of } \\
\text { substrate } \\
\text { units }\end{array}$ & $\begin{array}{l}\text { The share } \\
\text { of the } \\
\text { substrate } \\
(\%)\end{array}$ & $\begin{array}{c}\text { The } \\
\text { number of } \\
\text { thalli }\end{array}$ & $\begin{array}{c}\text { Average } \\
\text { thalli area } \\
\left(\mathrm{cm}^{2}\right)\end{array}$ \\
\hline \multirow{9}{*}{$\begin{array}{l}\text { grass-bilberry } \\
\text { mixed spruce- } \\
\text { birch } \\
\text { communities }\end{array}$} & $\begin{array}{l}\text { Picea spp. } \\
\text { (live) }\end{array}$ & 2 & 2 & 4 & $21.7 \pm 15.8$ \\
\hline & $\begin{array}{l}\text { Populus tremula } \\
\text { (live) }\end{array}$ & 34 & 36 & 293 & $\mathbf{5 1 . 2} \pm 14.1$ \\
\hline & $\begin{array}{l}\text { Populus tremula } \\
\text { (fallen dead) }\end{array}$ & 2 & 2 & 28 & $\mathbf{2 1 8 . 0} \pm 94.4$ \\
\hline & \begin{tabular}{|l} 
Salix caprea \\
(live)
\end{tabular} & 27 & 28 & 168 & $\mathbf{5 0 7 . 7} \pm 120.2$ \\
\hline & $\begin{array}{l}\text { Salix caprea } \\
\text { (fallen dead) }\end{array}$ & 6 & 6 & 33 & $\mathbf{4 4 7 . 5} \pm 186.5$ \\
\hline & $\begin{array}{l}\text { Salix caprea } \\
\text { (standing dead) }\end{array}$ & 15 & 16 & 94 & $\mathbf{5 1 7 . 7} \pm 197.0$ \\
\hline & \begin{tabular}{|l|}
$\begin{array}{l}\text { Sorbus aucuparia } \\
\text { (live) }\end{array}$ \\
\end{tabular} & 3 & 3 & 5 & $\mathbf{5 3 9 . 6} \pm 138.8$ \\
\hline & \begin{tabular}{|l|}
$\begin{array}{l}\text { Sorbus aucuparia } \\
\text { (standing dead) }\end{array}$ \\
\end{tabular} & 3 & 3 & 10 & $\mathbf{2 0 8 . 2} \pm 103.1$ \\
\hline & Others & 3 & 3 & 7 & $\mathbf{5 7 . 4} \pm 35.6$ \\
\hline \multirow{5}{*}{$\begin{array}{l}\text { sub-climax } \\
\text { bilberry } \\
\text { feather-moss } \\
\text { spruce forest }\end{array}$} & $\begin{array}{l}\text { Picea spp. } \\
\text { (live) }\end{array}$ & 2 & 7 & 16 & $9.2 \pm 3.0$ \\
\hline & $\begin{array}{l}\text { Populus tremula } \\
\text { (live) }\end{array}$ & 13 & 48 & 178 & $35.7 \pm 8.4$ \\
\hline & $\begin{array}{l}\text { Salix caprea } \\
\text { (live) }\end{array}$ & 6 & 22 & 42 & $\mathbf{2 1 0 . 8} \pm 98.4$ \\
\hline & $\begin{array}{l}\text { Salix caprea } \\
\text { (standing dead) }\end{array}$ & 2 & 7 & 18 & $114.8 \pm 75.8$ \\
\hline & Others & 4 & 15 & 19 & $114.2 \pm 39.4$ \\
\hline
\end{tabular}

Table 3. Substrate types of Lobaria pulmonaria in forest communities of the north taiga subzone of Karelia. Notes: $\mathrm{M} \pm \mathrm{m}: \mathrm{M}$ - average value, $\mathrm{m}$ - standard error.

Therefore, the number of thalli increased (Fig. 2.A), and the average area decreased with an increase in the diameter and area of the trunk (Fig. 2.B).

The angle of inclination of the trunk surface is one of the most significant characteristics of the habitat of epiphytic lichens. Positively inclined trunks receive 2-3 times more moisture from the atmosphere than negatively inclined ones. They are better lit and contribute to better fixation of lichen diasporas (Barkman 1958, Gorshkov 1986, Tarasova et al. 2012).
Therefore, with an increase in the angle of inclination of the tree in a positive direction, the coverage and species diversity of epiphytic lichens increase (Gorshkov 1986, Tarasova 2000, Stepanova 2004, Zhuravleva 2007).

In the studied communities, L. pulmonaria occupies tree trunks with the inclination varying from -36 to $81^{\circ}$, with the average inclination of $+16^{\circ}$. On aspen, the most of thalli $(53 \%)$ grows on the trunks with inclination varying between 2 and $12^{\circ}$. 
The number of thalli (A)

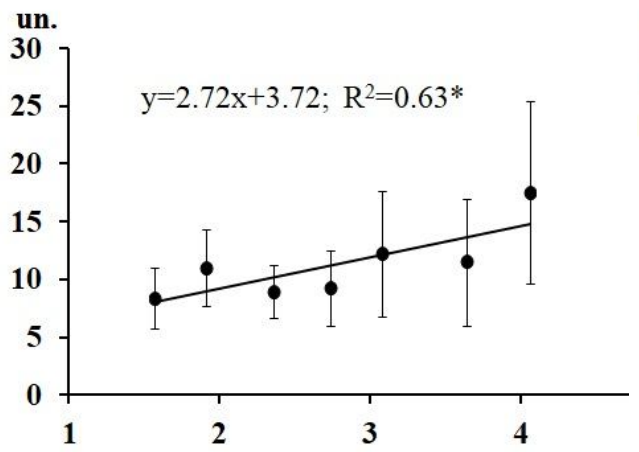

Average thalli area (B)

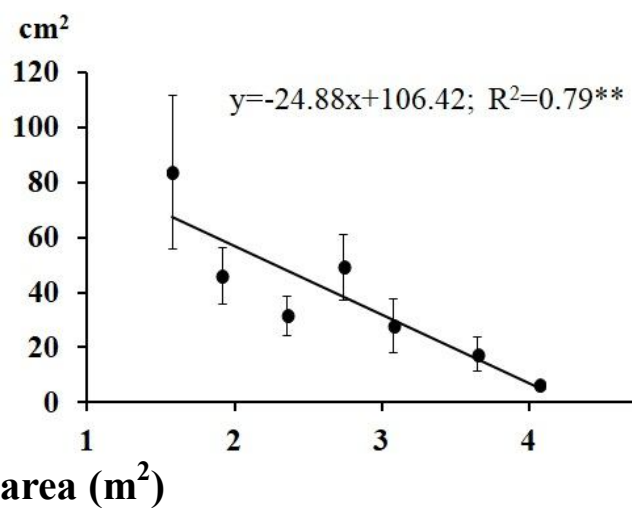

Fig. 2. Quantitative indicators of Lobaria pulmonaria on Populus tremula trees with different trunk lateral surface area in spruce phytocoenoses in the north taiga subzone. Notes: The lines are drawn in accordance with linear regression equations. Error bars indicate standard error of the mean $(*-p<0.05, * *-p<0.01) . R^{2}$ is the coefficient of determination.

Average thallus area (A)

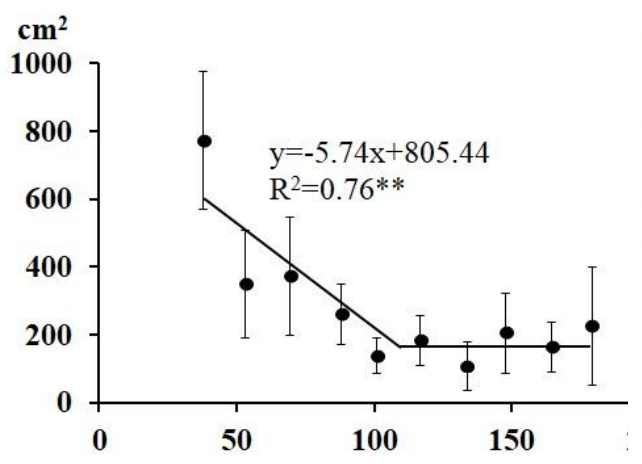

Average necrotic area (B)

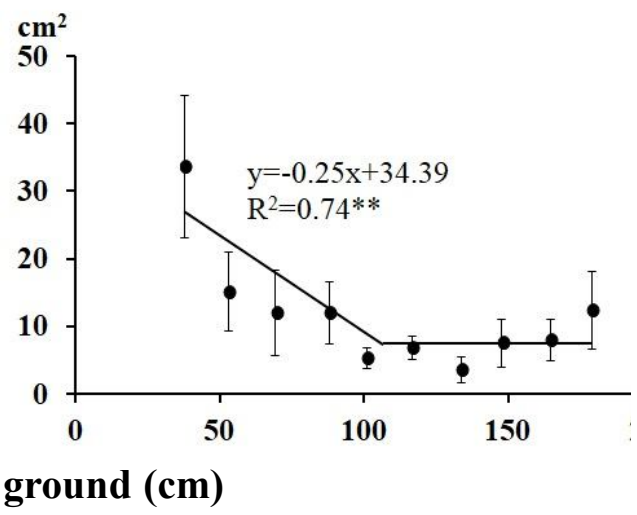

Fig. 3. Quantitative indicators of Lobaria pulmonaria on trunks of live Salix caprea trees at different heights above ground in spruce phytocoenoses in the north taiga subzone. Notes: The lines are drawn in accordance with linear regression equations. Error bars indicate standard error of the mean $(* *-p<0.01) . R^{2}$ is the coefficient of determination.

The largest number of L. pulmonaria thalli both on live $(62 \%)$ and dead-standing $(55 \%)$ willows was recorded on moderately $\left(5-26^{\circ}\right)$ inclined trunks.

The lichen thalli were recorded on trunks at a height of 6 to $192 \mathrm{~cm}$. On aspen, most thalli (76\%) grow at a height of
60 to $160 \mathrm{~cm}$, whileon willow $65 \%$ of thalli were found at a height of $60-140 \mathrm{~cm}$ above ground. In single cases, there were specimens growing at a height of more than $2 \mathrm{~m}$ above ground (not counted).

It was found that on willow trunks, the areas of L. pulmonaria thalli and necrotic 
areas decrease from 770 to $180 \mathrm{~cm}^{2}$ and from 30 to $10 \mathrm{~cm}^{2}$, respectively, with an increase in the height from the ground up to $110 \mathrm{~cm}$. With a further increase in the height from the ground these indices do not change (Fig. 3.A, 3.B). This is probably due to the fact that large, older thalli are located in the lower part of the trunk. As a rule, they are virgin $2 \mathrm{c}$ - senile thalli that account for $63-89 \%$ of the total number of thalli are located at a height of up to $1 \mathrm{~m}$ above ground.

Under conditions of the north taiga subzone area in Karelia, the thalli of L. pulmonaria on the trunks of live aspen were most often found on south-east and westsides of trees; they account for 17 and $16 \%$ of the thalli number, respectively (Fig. 4.A). The smallest number of thalli was recorded on north-east (7\%) and east (7\%) sides of trees. The average thallus area on the north, north-east and east sides is 2 times higher than on other sides of the trunk (Fig. 4.B).

On goat willow, $52 \%$ of thalli were found on north and north-west sides of trees (Fig. 5.A). The largest average area was recorded for thalli located on north, north-east, and north-west sides (Fig. 5.B). It was revealed that the contribution of necrosis to the total thalli area was greatest in thalli on south sides of willow trunks (Fig. 6.A), and north-east and westsides of aspen trunks (Fig. 6.B). However, the share of necrotic areas on north sides of aspen trees did not exceed 9\%, whereas on south sides of willow trees it reaches $20 \%$. This was probably due to longer stay of thalli in a dry state on south sides of $S$. caprea trunks as they were more likely to be exposed to direct sunlight than thalli at the same sides on $P$. tremula trunks. This was evidenced by a significant difference between the length and radius of the crown (U-test, $\mathrm{p}=0.05$ ) of $S$. caprea and P. tremula (Table 2). Due to the high values of tree height, radius and length of crown, stemflow on aspen can reach $9.4 \%$ of the total rainfall in the community (Molchanov 1961). Owing to the wide and dense crown, aspen trunks were in a wet state longer than those of willows.
The share of thalli (A)

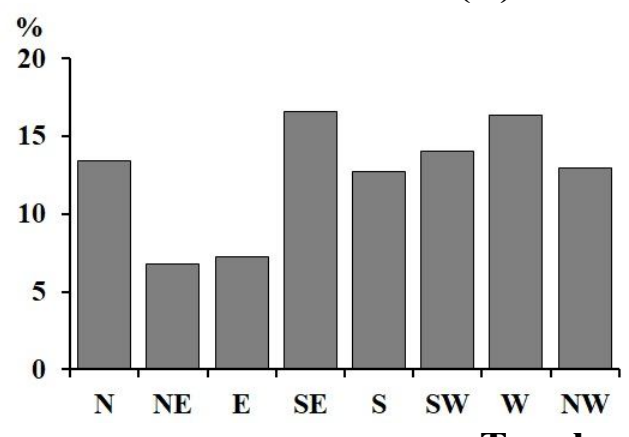

Average thallus area (B)

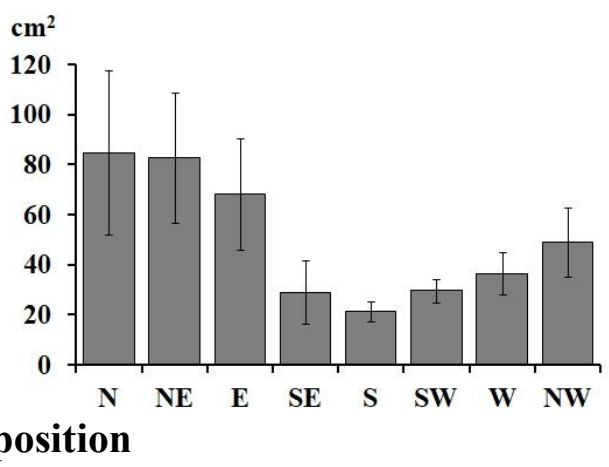

Fig. 4. Quantitative indicators of Lobaria pulmonaria at various Populus tremula trunk expositions in spruce phytocoenoses in the north taiga subzone. Notes: Error bars indicate standard error of the mean. 
The share of thalli (A)

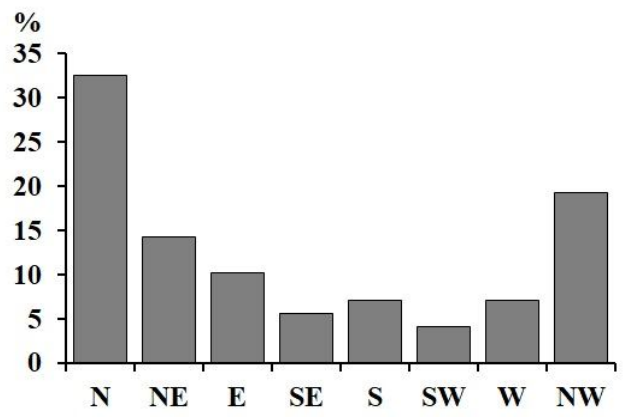

Average thallus area (B)

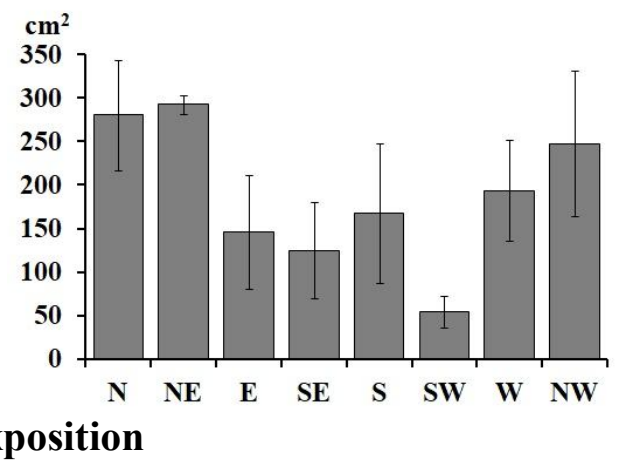

Fig. 5. Quantitative indicators of Lobaria pulmonaria at various Salix caprea trunk expositions in spruce phytocoenoses in the north taiga subzone. Notes: Error bars indicate standard error of the mean.

In forest phytocoenoses in the north taiga subzone the projective cover of bryophytes on the main substrates of $L$. pulmonaria (live willow and aspen trees) varied from 5 to $40 \%$ and from 5 to $30 \%$, respectively. It was revealed that on willow trees most of the thalli $(73 \%)$ are found on trunks with bryophyte cover of $10-20 \%$, while on aspen trees $53 \%$ of the studied thalli grow on trunks with similar bryophyte covering. Interestingly, 23\% of L. pulmonaria thalli are found on aspen trees with an abundance of bryophytes up to $5 \%$. This probably also indicates that $P$. tremula trunks remain moist for a longer time than trunks of $S$. caprea.

\section{(A)}

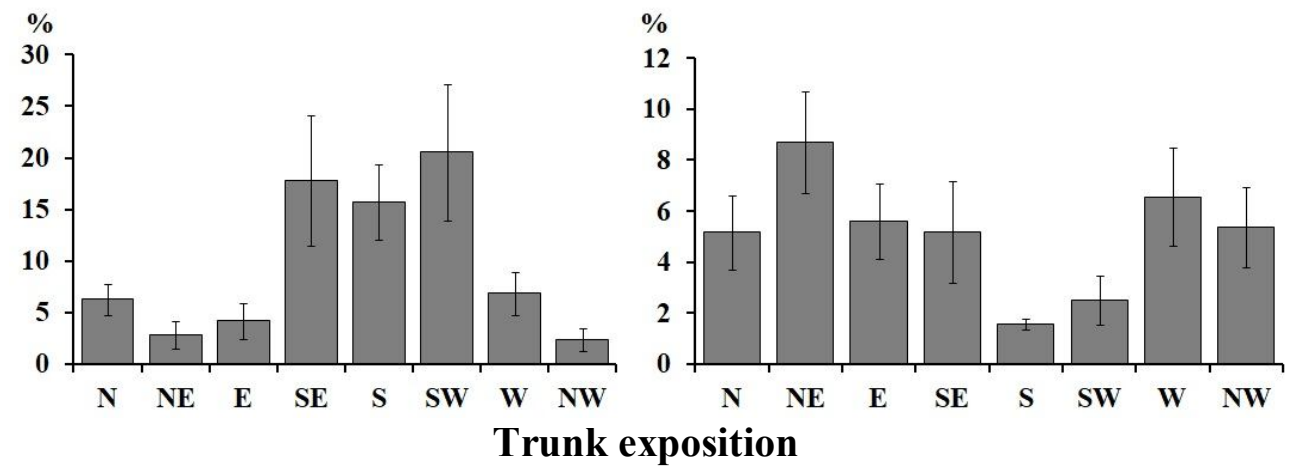

Fig. 6. The average share of necrotic area in the total thallus area of Lobaria pulmonaria at different trunk expositions of Salix caprea (A) and Populus tremula (B) in spruce phytocoenoses in the north taiga subzone. Notes: Error bars indicate standard error of the mean. 


\section{Discussion}

At the total length of reconnaissance routes of $\sim 110 \mathrm{~km}$, only a few habitats of L. pulmonaria were found in forest communities in the north taiga subzone. In the studied territory, L. pulmonaria was found in spruce phytocoenoses with a time since last disturbance of 180 years or more. In the middle taiga subzone, the species was recorded in middle-aged aspen forests as soon as 80 years after the disturbance (Ignatenko and Tarasova 2018).

One of the main reasons of rare findings of $L$. pulmonaria in the north of the region was the absence of its main substrate, which is P. tremula for taiga (Istomina 1996, Kravchenko and Fadeeva 2008, Pystina and Semenova 2009, Mikryukov 2011, Ignatenko and Tarasova 2015, 2017, 2018; Ignatenko 2018). Pure aspen forests in northwest Russia are found only in the middle taiga subzone (Volkov 2008). In northern taiga forests, aspen was found only as a small admixture in birch forests and mixed spruce-birch communities. Due to this, on the northern limits of the range, the species is often found also on $S$. caprea since the bark of this tree is similar in structure (cracked), mineral content and $\mathrm{pH}$ to P. tremula (Gauslaa 1995). However, $S$. caprea is significantly inferior to $P$. tremula in its taxation parameters, which affects the qualitative and quantitative characteristics of $L$. pulmonaria subpopulations. Thus, the tree age and trunk area of $S$. caprea are lower than that of $P$. tremula, which means that the potential space and time for the growth and development of lichen thalli is smaller on this substrate.

It is important to note that in the subzone of the middle taiga, L. pulmonaria grows in bilberry feather-moss spruce forest quite often. The species has established in the ecosystem since last disturbance of 410-450 years (likely due to the felling or forest fires) (Ignatenko and Tarasova 2017,
2018). This is probably due to the renewal of aspen in such communities in the windows after windthrow. The fact that L. pulmonaria massively populates the lower branches of young spruce trees also contributes to maintaining a high number of thalli in these forests. In old-growth northern taiga spruce forest with the time since last disturbance of more than 400 years (Paanajarvi National Park), there is no suitable substrate for the colonization of $L$. pulmonaria. Therefore, the species is not found in these phytocoenoses. In Kostomuksha Nature Reserve, as in the whole in the subzone of northern taiga, pine phytocoenoses predominate $(85 \%)$, spruce communities account for only $14.5 \%$, which are confined to the foot of the slopes and valleys of rivers and streams (Gromtsev 2009). Pine forests are potentially unsuitable for the distribution of the species, and fragments of spruce phytocoenoses can act as a kind of passages for the settlement of L. pulmonaria.

It has been found that at the limits of the range, the number of substrate units colonized by L. pulmonaria and the number of thalli is smaller than in the southern Karelia in similar types of forests with the same time since last disturbance (Ignatenko and Tarasova 2017, 2018; Ignatenko 2018). The share of generative thalli in the ontogenetic spectrum of species populationsin forest communities of the north taiga subzone is 3 times less than in mid-taiga communities. This is probably due to the high degree of fragmentation of this territory by pine phytocoenoses and the lack of suitable substrate, i.e. aspen and willow trees. In this regard, the frequency of occurrence of L. pulmonaria in the communities of the north taiga subzone decreases and leads to a decrease in the probability of fruiting bodies forming on the thalli, since thalli with a different genotype are required for sexual reproduction (Zoller et al. 1999). It 
is believed that the presence of sexual reproduction is characteristic of populations with high density (Scheidegger et al. 1995).

Colonizing and stable subpopulations predominate in the subpopulation spectrum in mid-taiga forests (Ignatenko and Tarasova 2018), while colonizing and extending subpopulations predominate in northern taiga. The data obtained indicate the relative biological youth of the studied subpopulations (Mikhailova 2005). A low proportion of regressive subpopulations indicates that in the vast majority of cases, reproduction in subpopulations after colonization of the substrate proceeds normally.

The results have shown that the diameter and area of the tree significantly affect the characteristics of L. pulmonaria - with an increase in these parameters of the trunk, the number of thalli increases and the average area decreases. Such changes in subpopulations may indicate the appearance of new thalli generations arising from maternal ones on large old trees (Ignatenko 2018, Ignatenko and Tarasova 2019). With the growth of a tree, a large number of different microbiotopes are formed on the aspen and willow bark (crevices, pores, roughness), and the substrate area increases, which has a positive effect on the growth and development of L. pulmonaria thalli (Gustafsson et al. 1992, Mikhailova et al. 2005, Öckinger et al. 2005, Ranius et al. 2008, Belinchón et al. 2009). The time factor is also important. Large, older trees are available for colonization over a longer period of time ( $\mathrm{Gu}$ et al. 2001, Belinchón et al. 2009, Fritz et al. 2009, Brunialti et al. 2015). Similar data were obtained when populations of L. pulmonaria were studied in the mid-taiga forest of Karelia (Ignatenko 2018, Ignatenko and Tarasova 2019).

For epiphytic lichens, an important role is played by the individual characteristics of every trunk. L. pulmonaria grows in most cases on positively inclined surfaces of trees in northern taiga spruce forests, exposed to the north and west, at the height of more than $60 \mathrm{~cm}$ above ground. This is probably due to the requirement of a long stay of the thallus in a wet state for the successful growth of L. pulmonaria, as well as the absence of direct sunlight. Light plays an important role in the life of the lichen, however, direct sunlight can cause serious damage to the thallus and lead to its death (Gauslaa and Solhaug 2001). The damaging effect of strong solar insolation is probably indicated by the fact that the proportion of necrotic areason the thalli of $L$. pulmonaria growing on $S$. caprea was higher on the trunks with south exposure.

In phytocoenoses of the mid-taiga subzone, L. pulmonaria was recorded on the trunk with similar characteristics (Ignatenko 2018). At the same time, as well as on $S$. caprea trunks in the north taiga subzone, the average area of thallus necrosis on $P$. tremula decreases with increasing height above ground up to $1 \mathrm{~m}$, and on the branches of Picea spp. up to $0.8 \mathrm{~m}$, then this parameter stabilizes. This is probably due to less favorable conditions for the growth and development of L. pulmonaria thallion the lower part of the trunk: snow cover, competition with bryophytes, etc.

Epiphytic bryophytes play an important role in the microenvironment in lichen habitats. The developed moss cover on trees helps to maintain an appropriate level of moisture, which in turn has a beneficial effect on the growth and development of cyanolichens, compared to habitats where bryophytes are absent (Tarasova 2017, Tarasova et al. 2017). Thus, in forest phytocoenoses in northern Karelia, the largest number of thalli was recorded on the trunks of the main substrates, where the projective cover of bryophytes was $10-20 \%$. In the south of the region, with an increase in the total coverage of bryophytes from 3 to $60 \%$, the number of $L$. pulmonaria thalli on aspen trunks increases 3 times (from 3 to 9 pcs.) and the average thallus area decreases 2 times (from 115 to $65 \mathrm{~cm}^{2}$ ) (Ignatenko 2018). 


\section{Conclusions}

As a result of the studies, it becomes apparent that populations of L. pulmonaria in the northern taiga forests of Karelia are vulnerable to changes in environmental conditions and need a special protection. The absence of suitable substrates and peculiar climatic conditions leads to a decrease in the density of populations, which probably has a significant effect on the genetic diversity of the species in the region.

\section{References}

Andreeva, E. N., Bakkal, I. Yu., Gorshkov, V. V., Lyanguzova, I. V., Maznaya, E. A., Neshataev, V. Yu., Neshataeva, V. Yu., Stavrova, N. I., Yarmishko, V. T. and Yarmishro, M. A. (2002): Guide for Analysis of Forest Communities. St. Petersburg State University, 240 p. (In Russian).

BARKMAn, J. J. (1958): Phytosociology and ecology of cryptogamic epiphytes. Assen, Netherlands van Gorcum Co, 628 p.

Batalov, A. E., Korepanov, V. I., Kocherina, E. V., Pucnina, L. V., Rai, E. A., Rykov, A. M, Rykova, S. Yu., Torkhov, S.V. and Churakova, E. Yu. (2005): Rare species of plants, animals and mushrooms of the forest ecosystems of the Arkhangelsk region and recommendations for their protection. Moscow: World Wide Fund for Nature, 96 p. (In Russian).

Belinchón, R., Martínez, I., Otálora, M. A., Aragón, G., Dimas, J. and Escudero, A. (2009): Fragment quality and matrix affect epiphytic performance in a Mediterranean forest landscape. American Journal of Botany, 96(11): 1974-1982.

BISKE, G. S. (1959): Quaternary deposits and geomorphology of Karelia. Petrozavodsk: State Publishing House of the KASSR, 307 p. (In Russian).

Brunialti, G., Frati, L. and Ravera, S. (2015): Structural variables drive the distribution of the sensitive lichen Lobaria pulmonaria in Mediterranean old-growth forests. Ecological Indicators, 53: 37-42.

Chirva, O. V., Nikerova, K. M., Androsova, V. I. and Ignatenko, R. V. (2019): Activity of catalase and superoxide dismutase in Lobaria pulmonaria from forest communities of middle and northernmost boreal zone (NW Russia). Czech Polar Reports, 9(2): 228-242. doi: 10.5817/ CPR2019-2-19.

Clerc, P., Scheidegger, C. and Ammann, K. (1992): Liste rouge des macrolichens de la Suisse. Botanica Helvetica, 102: 71-83.

Fritz, Ö., NikLASSON, M. and ChURSKI, M. (2009): Tree age is a key factor for the conservation of epiphytic lichens and bryophytes in beech forests. Applied Vegetation Science, 12(1): 93-106.

GAUSLAA, Y. (1995): The Lobarion, an epiphytic community of ancient forests threatened by acid rain. The Lichenologist, 27(1): 59-76.

GauslaA, Y., Solhaug, K. A. (2001): Fungal melanins as a sun screen for symbiotic green algae in the lichen Lobaria pulmonaria. Oecologia, 126(4): 462-471.

Gorshkov, V. V. (1986): Epiphytic lichen synusiae of pine forests of the Kola Peninsula: Formation, ecology, influence of anthropogenic factors. Extended Abstract of Candidate of Sciences (Biol) Dissertation, Leningrad. 21 p. (In Russian).

GoRshKOV, V. V. (1998): Boreal forest communities: Formation and restoration of the stationary state of the forest ecosystems after external disturbances //The role of virgin terrestrial biota in modern conditions of global environmental changes: Biotic regulation of the environment, Gatchina, 138-190. (In Russian).

GorshKov, V. V. (2001): Post-fire restoration of pine forests of the European North. Extended Abstract of Doctor of Sciences (Biol.) Dissertation, St. Petersburg, 35 p. (In Russian).

Goward, T., ARSENAUlt, A. (2000): Cyanolichen distribution in young unmanaged forests: A dripzone effect? The Bryologist, 103(1): 28-37. 
Gromtsev, A. N. (2003): Landscape models of the primeval forests. Biotic diversity of Karelia: conditions of formation, communities and species. Ed. Gromtsev, A. N., Kitaev S. P., Krutov V. I., Kuznetsov O. L., Lindholm T., Yakovlev E. B. Petrozavodsk: Karelian Research Center of RAS, pp. 47-50. (In Russian).

Gromtsev, A. N. (2007): Dynamics of indigenous taiga forests in the European part of Russia with natural disturbances. Actual problems of geobotany. III All-Russian School-Conference, Petrozavodsk, pp. 283-301. (In Russian).

Gromtsev, A. N. (2008): Fundamentals of landscape ecology of European taiga forests of Russia. Petrozavodsk: Karelian Research Center of the RAS. 238 p. (In Russian).

GromTsev, A. N. (2009): Forests of Kostomukshsky strict nature reserve: structure, dynamics, landscape patterns. Transactions of the Karelian Research Centre of RAS, 2: 71-78. (In Russian).

Gu, W. D., KuUsinen, M., Konttinen, T. and Hanski, I. (2001): Spatial pattern in the occurrence of the lichen Lobaria pulmonaria in managed and virgin boreal forests. Ecography, 24(2): 139150 .

Gustafsson, L., Fiskesjö, A., Ingelög, T., Petterssonj, B. and Thor, G. (1992): Factors of importance to some lichen species of deciduous broad-leaved woods in southern Sweden. The Lichenologist, 24(3), 255-266.

IgNATENKo, R. V. (2018): Ecology of the lichen Lobaria pulmonaria (L.) Hoffm. in plant communities of Karelia. Extended Abstract of Candidate of Sciences (Biol.) Dissertation, St. Petersburg. 26 p. (In Russian).

IgnatenKo, R. V., TARAsova, V. N. (2015): Populations of threatened lichen Lobaria pulmonaria (L.) Hoffm. at different levels of anthropogenic load. Proceedings of Petrozavodsk State University. Biological Sciences, 8: 57-64. (In Russian).

Ignatenko, R. V., TARAsOVA, V. N. (2017): The population structure of the lichen Lobaria pulmonaria in the middle boreal forests depends on the time-since-disturbance. Folia Cryptogamica Estonica, 54: 83-94. doi: https://doi.org/10.12697/fce.2017.54.13

Ignatenko, R. V., Tarasova, V. N. (2018): Assessment of the state of lung lichen, Lobaria pulmonaria (L.) Hoffm., in forest communities with different times since disturbance in the northeast of European Russia. Russian Journal of Ecology, 49(4): 277-285.

IGNATENKO, R. V., TARASOVA, V. N. (2019): Influence of tree characteristics on the subpopulations of Lobaria pulmonaria (L.) Hoffm. in the forest communities of Karelia. Ecology and Evolution: New Horizons: Proceedings of the International Symposium on the $100^{\text {th }}$ Anniversary of Academician S. S. Schwartz, Yekaterinburg, pp. 41-44. (In Russian).

Ignatenko, R. V., TARAsova, V. N. and Markovskaya, E. F. (2020). Ontogenesis of the lichen Lobaria pulmonaria (L.) Hoffm. in plant communities of the Boreal Zone. Russian Journal of Developmental Biology, 51(2): 115-124.

IstominA, N. B. (1996): The Biology of Lobaria pulmonaria (L.) Hoffm. And Menegazzia terebrata (Hoffm.) Massal. in the southern taiga forests of European Russia, Extended Abstract of Candidate of Sciences (Biol.) Dissertation, Moscow, 24 p. (In Russian).

Ivanter, E. V., Korosov, A. V. (2011). Introduction to quantitative biology. Petrozavodsk: Petrozavodsk State University. 302 p. (In Russian).

JÜRIADO, I., LIIRA, J. (2009): Distribution and habitat ecology of the threatened forest lichen Lobaria pulmonaria in Estonia. Folia Cryptogamica Estonica, 46: 55-65.

Kadetov, N. G., Suslova, E. G. (2019): Protection of steppe plants near the northern border of the range in the Moscow region. Problems of Steppe Science, 15: 126-129. (In Russian). doi: 10.2441 / 9999-006A-2019-11519.

KravChenKo, A. V., FAdEeVA, M. A. (2008): Distribution and condition of Lobaria pulmonaria in the southeast of Fennoscandia. Lichens of boreal forests and Fourth Russian lichenological field school. Proceedings of the international conference, Syktyvkar, pp. 60-74. (In Russian).

Markovskaya, E. F., D'YachKova, T. YU. and Morozova, K. V. (2018): Nymphoides peltata (S. G. Gmel.) O. Kuntze (Menyanthaceae) at the border of geographic range: Anatomical and morphological features. Hortus Botanicus, 13: 291-303. doi: 10.15393/j4.art.2018.5322 
Mikhailova, I. N. (2005): Analysis of the subpopulation structure of epiphytic lichens (using Lobaria pulmonaria (L.) Hoffm. as an example). Bulletin of Nizhny Novgorod University named after N. I. Lobachevsky, 1(9): 124-134. (In Russian).

Mikhailova, I., Trubina, M., Vorobeichik, E. and Scheidegger, C. (2005): Influence of environmental factors on the local-scale distribution of cyanobacterial lichens: case study in the North Urals, Russia. Folia Cryptogamica Estonica, 41: 45-54.

Mikryukov, V. S. (2011): Population ecology of epiphytic lichen Lobariapulmonaria (L.) Hoffm.in the Urals and Siberia, Extended Abstract of Candidate of Sciences (Biol.) Dissertation, Yekaterinburg, 20 p. (In Russian).

Molchanov, A. A. (1961): Forest and climate. Moscow: Publishing House of the USSR Academy of Sciences, 279 p. (In Russian).

ÖCKInGer, E., NikLASSON, M. and NilsSON, S. G. (2005): Is local distribution of the epiphytic lichen Lobaria pulmonaria limited by dispersal capacity or habitat quality? Biodiversity and Conservation, 14(3): 759-773.

Pystina, T. N., Semenova, N. A. (2009): Ecological features of lichen Lobaria pulmonaria (Lobariaceae) in the Republic of Komi. Botanical Journal, 94(1): 48-58. (In Russian).

Ranius, T., Johansson, P., Berg, N. and Niklasson, M. (2008): The influence of tree age and microhabitat quality on the occurrence of crustose lichens associated with old oaks. Journal of Vegetation Science, 19(5): 653-662.

Richardson, D. H., CAmeron, R. P. (2004): Cyanolichens: Their response to pollution and possible management strategies for their conservation in northeastern North America. Northeastern Naturalist, 11(1): 1-22.

Romanov, A. A. (1961): About the Karelia climate. Petrozavodsk: State Publishing House of the Karelian ASSR, 139 p. (In Russian).

Scheidegger, C., Bilovitz, P. O., Werth, S., Widmer, I. and Mayrhofer, H. (2012): Hitchhiking with forests: population genetics of the epiphytic lichen Lobaria pulmonaria in primeval and managed forests in southeastern Europe. Ecology and Evolution, 2(9): 2223-2240.

Scheidegger, C., Frey, B. and WAlser, J. C. (1998): Reintroduction and augmentation of populations of the endangered Lobaria pulmonaria: methods and concepts. Lobarion lichens as indicators of the primeval forests of the Eastern Carpathians. Ukrainian Phytosociological Centre, Kiev, pp. 33-52.

Scheidegger, C., Frey, B. and Zoller, S. (1995): Transplantation of symbiotic propagules and thallus fragments: methods for the conservation of threatened epiphytic lichen populations. Mitteilungen der Eidgenössischen Forschungsanstaltfür Wald, Schnee und Landschaft, 70(1): 41-62.

Sidorova, O. V., Churakova, E.Yu. (2010): Rare and endangered species of vascular plants and leafy mosses of the central part of Belomor-Kuloi plateau. Bulletin of the Pomeranian university. Series: Natural Sciences, 4: 72-79. (In Russian).

Stavrova, N. I., Gorshkov, V. V. and Katyutin, P. N. (2016): Formation of the structure of cenopopulations of forest forming species in the process of post-fire recovery of northern forests. Transactions of the Karelian Research Centre of RAS, Series Biogeography, 3: 10-28. (In Russian).

StePAnOVA, V. I. (2004): Epiphytic lichen cover of Norway spruce (Picea abies (L.) Karst.) in spruce forests of the southern Karelia. Extended Abstract of Candidate of Sciences (Biol.) Dissertation, St. Petersburg, 28 p. (In Russian).

TARAsova, V. N. (2000): Epiphytic lichen cover of the main types of pine forests in the southern Karelia and its formation, Extended Abstract of Candidate of Sciences (Biol.) Dissertation, St. Petersburg, 28 p. (In Russian).

TARASOVA, V. N. (2017): The structure and dynamics of the epiphytic moss-lichen cover in the mid-taiga forests of the north-west of the European part of Russia, Extended Abstract of Doctor of Sciences (Biol.) Dissertation, St. Petersburg, 46 p. (In Russian).

Tarasova, V. N., Androsov, V. I. and Sonina, A.V. (2012): Lichens. Physiology, Ecology, Lichen Indication. Petrozavodsk: Publishing House of PetrSU, 268 p. (In Russian). 
TARasova, V. N., OBabko, R. P. and Ignatenko, R. V. (2017): Lichens and bryophytes associated with Lobaria pulmonaria (L.) Hoffm. in the forest communities of the middle taiga subzone of the Republic of Karelia. Boreal forests: State, Dynamics, Ecosystem Services, Petrozavodsk, pp. 288-290. (In Russian).

Volkov, A. D. (2008): Forest Types in Karelia. Petrozavodsk: Karelian Research Center of the RAS. 180 p. (In Russian).

YoshIMURA, I. (1998): Lung lichens and their vegetation in Japan and the other regions. Lobarion lichens as indicators of the primeval forests of the Eastern Carpathians. Ukrainian Phytosociological Centre, Kiev, pp. 53-63.

ZhURAVLEVA, S. E. (2007): Epiphytic lichen communities of undisturbed and disturbed habitats. Actual problems of geobotany. III All-Russian School-Conference, Petrozavodsk, pp. 184-188. (In Russian).

Zoller, S., Lutzoni, F. and SCheidegGer, C. (1999): Genetic variation within and among populations of the threatened lichen Lobaria pulmonaria in Switzerland and implications for its conservation. Molecular Ecology, 8(12): 2049-2059.

\section{Web sources / Other sources}

[1] Red Book of the Murmansk region. Kemerovo: Asia-Print (2014). 584 p. (In Russian).

[2] Red Book of the Nenets Autonomous Okrug. Naryan-Mar: Nenets Information and Analytical Center (2006). 450 p. (In Russian). 